\title{
Grand challenges in marine biogeochemistry
}

\author{
Eric P. Achterberg * \\ Chemical Oceanography Group, Marine Biogeochemistry Division, GEOMAR Helmholtz Centre for Ocean Research Kiel, Kiel, Germany \\ *Correspondence: eachterberg@geomar.de
}

Edited and reviewed by:

Antonio Tovar-Sanchez, CSIC (IMEDEA), Spain

Keywords: marine biogeochemistry, oceanic carbon and nutrient cycling, trace element biogeochemistry, air-sea exchange of greenhouse gases, oceans and climate change

\section{INTRODUCTION}

The ocean plays a central role in our earth's climate system and also provides a range of important ecosystem services, including food, energy, transport, and nutrient cycling. Marine biogeochemistry focuses on the study of complex biological, chemical, and physical processes involved in the cycling of key chemical elements within the ocean, and between the ocean and the seafloor, land and atmosphere. The ocean is increasingly perturbed by human induced alterations to our planet, including anthropogenic emissions of nitrogen, phosphorus, carbon and trace elements, and climate change. The establishment of a detailed understanding of biogeochemical processes, including their rates, is essential to the identification and assessment of climatic and chemical feedbacks associated with changes in the chemical and physical environment that are mediated through ocean biology, chemistry and physics. Important research areas in marine biogeochemistry involve the cycling of organic and inorganic forms of carbon, nitrogen and phosphorus, the cycling and biological roles of essential trace elements, and the fate and climatic impact of marine produced trace gases.

\section{GREENHOUSE GASSES}

The concentrations of atmospheric greenhouse gases (GHGs; primarily $\mathrm{CO}_{2}, \mathrm{CH}_{4}$ and $\mathrm{N}_{2} \mathrm{O}$ ) are currently ca. $40 \%$ higher for $\mathrm{CO}_{2}, 150 \%$ for $\mathrm{CH}_{4}$ and $19 \%$ for $\mathrm{N}_{2} \mathrm{O}$ compared with pre-industrial levels (Myhre et al., 2013), and surpass levels seen over the past 650,000 years or more. Furthermore, there is no paleo analogue available for the present rate of increase in the atmospheric GHG concentrations. The anthropogenic inputs of the GHGs interact with their natural cycles in the oceans and troposphere, resulting in climate feedbacks and impacts on the environment. The ocean takes up about one quarter of the anthropogenic $\mathrm{CO}_{2}$ emissions (ca. $10 \mathrm{Pg} \mathrm{C}$ per year) (Canadell et al., 2007), and as a consequence the accumulation in the atmosphere is reduced (Le Quere et al., 2009). Whilst our understanding of the oceanic carbonate system is well developed at a fundamental level, there are still important questions about the regional, seasonal, and multi-annual variability of ocean uptake of $\mathrm{CO}_{2}$, and the biological and physical processes that determine this uptake and their variability. On-going observational studies with improved methodologies, including novel autonomous carbonate chemistry sensors (e.g., Martz et al., 2010; Rérolle et al., 2012), will provide answers to these questions over the coming years. Furthermore, we can expect an improved knowledge of the role of biological processes in oceanic $\mathrm{CO}_{2}$ uptake from a combined use of ocean color remote sensing tools, in-situ observations and modeling activities, (e.g., Friedrich and Oschlies, 2009).

An important step-change in our understanding and quantification of the physical air-sea transfer of $\mathrm{CO}_{2}$ and other GHGs is required, as the current modeling of this key process is underdeveloped and primarily driven through dependencies on windspeed only. New measurement approaches for GHGs are becoming available, such as eddy-covariance (Miller et al., 2010) which, with improved physical parameterization will lead to new insights and improved quantification of physical air-sea exchange of GHGs. Surface active components (surfactants) of the sea surface microlayer influence air-sea exchange through acting as a physicochemical barrier and through modifications of the sea surface hydrodynamics (Cunliffe et al., 2013). A major uncertainty in the determination of the air-sea exchange lies in the unknown role of biologically produced surfactants in modifying gas transfer, which can be suppressed by $5-50 \%$ as a result of natural phytoplankton exudates (Frew et al., 1990). Work is required in different biogeochemical regimes and over seasonal cycles and varying wind strengths to compare the effects of different surfactant levels and compositions on air-sea exchange of GHGs.

Our understanding of the global cycles of $\mathrm{N}_{2} \mathrm{O}$ and $\mathrm{CH}_{4}$ is less developed compared with $\mathrm{CO}_{2}$, which is a concern as these GHGs have significantly stronger effects on radiative forcing than $\mathrm{CO}_{2}$. Changing oceanic conditions, in terms of warming, water column stratification, nutrient status, acidification, and de-oxygenation, will potentially result in changes in oceanic emissions of these GHGs (e.g., Nevison et al., 2003; Berndt et al., 2014). However, our understanding of the production and removal of these gases is only just emerging, as are global maps of their emissions which currently only concern a 20 year old effort on $\mathrm{N}_{2} \mathrm{O}$ by Nevison et al. (1995), and no climatology for $\mathrm{CH}_{4}$ yet. Increased research efforts are therefore underway and for example promoted by Scientific Committee on Ocean Research (SCOR) working group 143 (Working toward a global network of ocean time series measurements of $\mathrm{N}_{2} \mathrm{O}$ and $\mathrm{CH}_{4}$ ).

\section{CHANGING OCEANS}

The polar regions are strongly influenced by climate change and will be subject to intensive research activities in future years. 
The Arctic region faces dramatic changes including rapid sea ice loss, alterations to $\mathrm{CO}_{2}$ exchange, acidification, increased freshwater inputs with associated carbon supply through terrestrial run off (e.g., Stroeve et al., 2007; Manizza et al., 2013). Whilst our understanding of the productivity in the contemporary Arctic Ocean is underdeveloped, for example, in relation to primary productivity in sea ice systems (Arrigo et al., 2012), future changes to primary and bacterial productivity will be challenging to predict. Upcoming research activities will need to provide detailed insights into the functioning of biogeochemical processes and ecosystems in the Arctic Ocean and thereby facilitate projections under future climate conditions.

The Southern Ocean plays a central role in the earth climate system as a global hub in overturning circulation (Marinov et al., 2006), and a key region for ocean $\mathrm{CO}_{2}$ uptake (Le Quere et al., 2009). This ocean region is facing important changes with reported warming of waters up to ca. $1100 \mathrm{~m}$ (Levitus et al., 2005), and shifts in wind patterns which involve strengthening of mid-latitude westerlies related to an increasingly positive Southern Annular Mode Index (Marshall et al., 2004). The changing wind patterns are postulated to enhance upwelling of relatively warm circumpolar deep waters (CDW) and flooding of Antarctic continental shelves (Jacobs, 2006), resulting in glacier melt (e.g., Pine Glacier) (Holland et al., 2008; Jacobs et al., 2011; Dutrieux et al., 2014) and associated sea level rise. The more pronounced upwelling of CDW near the Antarctic continent is also thought to enhance primary productivity through increased Fe supply to high nitrate low chlorophyll (HNLC) waters (Planquette et al., 2013). The shifts in wind patterns and associated changes in mixing, upand downwelling patterns may change the Southern Ocean $\mathrm{CO}_{2}$ sink, thereby providing unknown climatic feedbacks. The implications of changes to the Southern Ocean carbon cycle are very important to the earth climate system, but the current uncertainties are significant. Major future research efforts are foreseen in the high latitude oceans. The Arctic and Southern Ocean are currently undersampled with significant challenges of data collection using vessels due to inhospitable conditions in autumn and winter periods, when important transfers of $\mathrm{CO}_{2}$ to deep waters occur. The more widespread deployment of autonomous platforms (e.g., gliders/Argo floats) with biogeochemical sensors is envisioned within the next years and would transform our observational capabilities (Johnson et al., 2009).

Climate change is considered to result in the expansion of the low nitrate low chlorophyll (LNLC) regions (Steinacher et al., 2010), which currently occupy ca. $60 \%$ of the world's ocean and are characterized by chlorophyll a concentrations $<0.07 \mathrm{mg} . \mathrm{m}^{-3}$, but nevertheless play an important role in the global carbon cycle (Lomas et al., 2010; Steinacher et al., 2010). Deposition of aerosols to these regions forms a key supply of nutrients (e.g., N, P) and also trace elements (e.g., Fe, Co, Mn, Zn) to surface ocean microbial communities. Whereas the atmospheric supply of Fe to HNLC regions has been a focus of attention in recent years (Jickells et al., 2005), this focus is shifting toward the LNLC regions. Indications are that the supplies to these regions are incorrectly represented in models, with the pulsed aerosol supplies providing more pronounced effects on dinitrogen fixation and heterotrophy than the continuous supply currently assumed (Guieu et al., under review). Therefore, improved long-term observations of aerosol inputs to LNLC regions, in combination with measurements of surface water chemistry and microbial community diversity and microbial rates are required. This will allow improved parameterizations of ocean biogeochemical models for LNLC regions and facilitate projections of climate change related alterations to aerosol inputs on ocean productivity, nitrogen, and carbon cycles.

Shelf seas have been receiving increased attention in recent years, partly due to the recognition of their importance for ecosystem services. They comprise only about $5 \%$ of the global ocean, yet support 15-20\% of global primary productivity (Simpson and Sharples, 2012) and form an important interface between the land and the ocean. On a global scale, ca. $30 \%$ of the air-to-sea $\mathrm{CO}_{2}$ flux occurs in shelf seas (Chen and Borges, 2009), and the shelves are estimated to contribute to $>40 \%$ of particulate carbon sequestration (Muller-Karger et al., 2005; Regnier et al., 2013). The exact mechanisms responsible for these processes are not fully clear, which hampers our ability to project the effects of future climate change, and other anthropogenic pressures, on the ability of these systems to absorb $\mathrm{CO}_{2}$ (Regnier et al., 2013). The pressures on the coastal seas include overfishing, rising water temperatures, pollution inputs, acidification, eutrophication, and de-oxygenation (Rabalais et al., 2009). Therefore, further efforts are required to constrain the carbon fluxes in the contemporary shelf seas with a view to allow predictions of fluxes under future climate conditions.

\section{MULTIPLE STRESSORS IMPACTING BIOGEOCHEMICAL PROCESSES}

The influence of single forcing factors on biogeochemical cycles and marine ecosystems has been an active area of research over the last decades. This work includes the influence of macronutrients (Timmermans et al., 2004), cobalt (Saito et al., 2002) and iron (Nielsdóttir et al., 2009) additions on the functioning and structure of microbial communities, effects of temperature (Eppley, 1972), light (Falkowski and Raven, 2007) and $\mathrm{CO}_{2}$ (Hein and Sand-Jensen, 1997) on primary productivity, and effects of iron (Schlosser et al., 2014) and $\mathrm{CO}_{2}$ (Hutchins et al., 2007) on dinitrogen fixation. The future ocean is predicted to face a multitude of changes, including warming and increased water column stratification, reductions in ice cover, enhanced reactive nitrogen inputs, changes in atmospheric dust deposition, spread and intensification of oxygen minimum zones and ocean acidification (Gruber, 2011; Guieu et al., under review). Combined effects of two or more of these future changes on ocean biogeochemical cycles and ecosystems are challenging to predict as additive, synergistic and antagonistic effects may occur in addition to transitions in oceanic microbial communities. Research on the effects of multiple stressors on marine biogeochemical cycles and ecosystems is still in an initial phase, but will increase in volume despite significant logistical and intellectual challenges involved in the 
experimental and interpretation stages. A number of approaches to achieve this are currently employed, including laboratory experiments, mesocosm studies, and also oceanic observational studies conducted across strong biogeochemical and physical gradients. Current research efforts are focused on the impacts and feedbacks of combinations of forcing factors including high $\mathrm{pCO}_{2}$, nutrient limitation, Fe availability, aerosol dust addition, oxygen, and temperature. An important outstanding question involves the hypothesized decrease in strength of the biological carbon pump due to reduced $\mathrm{CaCO}_{3}$ ballasting and decreased size of phytoplankton cells in a more acidic, warmer, stratified and increasingly oligotrophic ocean. Furthermore, the combined effects of ocean acidification, de-oxygenation, water column stratification and (micro-) nutrient supply changes on dinitrogen fixation, nitrification, denitrification, and $\mathrm{N}_{2} \mathrm{O}$ emissions forms a key research area due to the central role of the nitrogen cycle in global ocean productivity.

\section{BASIN SCALE OBSERVATIONS OF TRACE ELEMENTS AND ISOTOPES: GEOTRACES}

Major international observational programmes including GEOSECS, JGOFS, and WOCE mapped the global oceanic distributions of the macronutrients $\mathrm{N}$, $\mathrm{P}$ and $\mathrm{Si}$ and provided understanding of the processes involved in their biogeochemical cycling. The GEOTRACES programme (Henderson et al., 2007) is underway since 2004, with currently about 30 completed cruises, and as main aim to develop an understanding of the distribution and cycling of trace elements and isotopes to complement our knowledge of the macronutrients. This programme has been made possible by improved trace metal clean sampling methods and analytical techniques, and the emergence of high quality reference seawaters for trace metals (Cutter and Bruland, 2012; Anderson et al., 2014). The publications of this programme are now emerging, showing remarkable oceanic distributions of elements including Zn (Wyatt et al., 2014) and Fe (Nishioka et al., 2013) which indicate sources (including hydrothermal vents, benthic supply and atmospheric inputs), transport pathways and relationships with macronutrient cycles. The programme has also allowed us to understand the observed latitudinal migration of dinitrogen fixation in the tropical Atlantic, which is forced by the seasonal shifts of the Intertropical Convergence Zone and associated supply of the essential micronutrient $\mathrm{Fe}$ by wet deposition (Schlosser et al., 2014). Wet and dry aerosol inputs form an important but poorly constrained source of trace metals and nutrients to the surface ocean (Baker et al., 2007), with many outstanding questions regarding solubility of elements following aerosol deposition in the surface waters, (e.g., Baker and Croot, 2010). Aerosol collection on the GEOTRACES cruises, in combination with surface water measurements, will provide unique and important new information on the role of aerosols in marine biogeochemical cycles and ecosystems.

The emerging datasets from the GEOTRACES programme for trace elements and their isotopes will provide pivotal information for modelers to improve their models of the oceanic carbon cycle. Present models typically have at best a rather simple representation of the key micronutrient Fe, limiting the accuracy of the models' response to drivers involving changes in strengths of micronutrient supplies and removal mechanisms. Important future changes in micronutrient cycles through processes such as increased continental aridity, ocean acidification, or decreasing ocean oxygen levels can only be modeled through improvements of our representation of these processes in biogeochemical models. A key upcoming challenge will be to improve our understanding of the scavenging and stabilisation processes of trace elements (notably $\mathrm{Fe}$ ) in the ocean. The emerging full ocean depth datasets of trace elements and indicators of elemental scavenging [radionuclides ${ }^{234} \mathrm{Th}$ and ${ }^{238} \mathrm{U}$ (Honeyman et al., 1988)], in combination with modeling approaches, will likely allow us to understand and quantify the scavenging rates in the global oceans.

\section{CONCLUSION}

Progress in marine biogeochemistry is driven by innovations in observational capabilities, which yield an improved assessment of climatic and chemical feedbacks (e.g., GEOTRACES). There is currently a drive toward increased use of biological and chemical sensors on autonomous platforms, providing large high frequency temporal and spatial data sets which will require multi-disciplinary data convolution approaches, directly linked to modeling efforts. The revolution in our data-acquisition approaches will require training of the new generation of marine biogeochemists in the statistical and numerical skills needed to handle complex chemical, biological, and physical datasets.

\section{ACKNOWLEDGMENTS}

I acknowledge funding by the UK Natural Environment Research Council, and the German Research Foundation Collaborative Research Center 754 (DFG SFB754) Programme on ClimateBiogeochemistry Interactions in the Tropical Ocean.

\section{REFERENCES}

Anderson, R. F., Mawji, E., Cutter, G. A., Measures, C. I., and Jeandel, C. (2014). GEOTRACES: changing the way we explore ocean chemistry. Oceanography 27, 50-61. doi: 10.5670/oceanog.2014.07

Arrigo, K. R., Perovich, D. K., Pickart, R. S., Brown, Z. W., Van Dijken, G. L., Lowry, K. E., et al. (2012). Massive phytoplankton blooms under arctic sea ice. Science 336, 1408. doi: 10.1126/science. 1215065

Baker, A. R., and Croot, P. L. (2010). Atmospheric and marine controls on aerosol iron solubility in seawater. Mar. Chem. 120, 4-13. doi: 10.1016/j.marchem.2008.09.003

Baker, A. R., Weston, K., Kelly, S. D., Voss, M. Streu, P., and Cape, J. N. (2007). Dry and wet deposition of nutrients from the tropical Atlantic atmosphere: links to primary productivity and nitrogen fixation. Deepsea Res. I Oceanogr. Res. Papers 54, 1704-1720. doi: 10.1016/j.dsr. 2007.07.001

Berndt, C., Feseker, T., Treude, T., Krastel, S. Liebetrau, V., Niemann, H., et al. (2014). Temporal constraints on hydrate-controlled methane seepage off svalbard. Science 343, 284-287. doi: 10.1126/science. 1246298

Canadell, J. G., Le Quéré, C., Raupach, M. R., Field, C. B., Buitenhuis, E. T., Ciais, P., et al. (2007). Contributions to accelerating atmospheric $\mathrm{CO} 2$ growth from economic activity, carbon intensity, and efficiency of natural sinks. Proc. Natl. Acad. Sci. U.S.A. 104, 18866-18870. doi: 10.1073/pnas.0702737104

Chen, C.-T. A., and Borges, A. V. (2009). Reconciling opposing views on carbon cycling in the coastal ocean: continental shelves as sinks and near-shore ecosystems as sources of 
atmospheric CO2. Deep Sea Res. II Top. Stud. Oceanogr. 56, 578-590. doi: 10.1016/j.dsr2. 2009.01.001

Cunliffe, M., Engel, A., Frka, S., Gašparović, B., Guitart, C., Murrell, J. C., et al. (2013). Sea surface microlayers: a unified physicochemical and biological perspective of the air-ocean interface. Prog. Oceanogr. 109, 104-116. doi: 10.1016/j.pocean.2012.08.004

Cutter, G. A., and Bruland, K. W. (2012). Rapid and noncontaminating sampling system for trace elements in global ocean surveys. Limnol. Oceanogr. Methods 10, 425-436. doi: 10.4319/lom.2012.10.425

Dutrieux, P., De Rydt, J., Jenkins, A., Holland, P. R., Ha, H. K., Lee, S. H., et al. (2014). Strong sensitivity of pine island ice-shelf melting to climatic variability. Science $343,174-178$. doi: 10.1126/science. 1244341

Eppley, R. W. (1972). Temperature and phytoplankton growth in the sea. Fishery Bull. 70, 1063-1085.

Falkowski, P. G., and Raven, J. A. (2007). Aquatic Photosynthesis. Princeton, NJ: Princeton University Press.

Frew, N. M., Goldman, J. C., Dennett, M. R., and Johnson, A. S. (1990). Impact of phytoplanktongenerated surfactants on air-sea gas exchange. J. Geophys. Res. Oceans 95, 3337-3352. doi: 10.1029/JC095iC03p03337

Friedrich, T., and Oschlies, A. (2009). Neural network-based estimates of North Atlantic surface $\mathrm{pCO} 2$ from satellite data: a methodological study. J. Geophys. Res. Oceans 114, C03020. doi: 10.1029/2007JC004646

Gruber, N. (2011). Warming up, turning sour, losing breath: ocean biogeochemistry under global change. Phil. Trans. R. Soc. A 369, 1980-1996. doi: 10.1098/rsta.2011.0003

Hein, M., and Sand-Jensen, K. (1997). CO2 increases oceanic primary production. Nature $388,526-527$. doi: $10.1038 / 41457$

Henderson, G. M., Anderson, R. F., Adkins, J., Andersson, P., Boyle, E. A., Cutter, G., et al. (2007). GEOTRACES - an international study of the global marine biogeochemical cycles of trace elements and their isotopes. Chemie Der Erde-Geochem. 67, 85-131. doi: 10.1016/j.chemer.2007.02.001

Holland, P. R., Jenkins, A., and Holland, D. M. (2008). The response of ice shelf basal melting to variations in ocean temperature. J. Clim. 21, 2558-2572. doi: 10.1175/2007JCLI1909.1

Honeyman, B. D., Balistrieri, L. S., and Murray, J. W. (1988). Oceanic trace metal scavenging: the importance of particle concentration. Deep Sea Res. 35, 227-246. doi: 10.1016/0198-0149(88)90038-6

Hutchins, D. A., Fu, F. X., Zhang, Y., Warner, M. E., Feng, Y., Portune, K., et al. (2007). CO2 control of Trichodesmium N-2 fixation, photosynthesis, growth rates, and elemental ratios: implications for past, present, and future ocean biogeochemistry. Limnol. Oceanogr. 52, 1293-1304. doi: 10.4319/lo.2007.52.4.1293

Jacobs, S. S. (2006). Observations of change in the Southern Ocean. Philos. Trans. R. Soc. Lond. A 364, 1657-1681. doi: 10.1098/rsta.2006.1794

Jacobs, S. S., Jenkins, A., Giulivi, C. F., and Dutrieux, P. (2011). Stronger ocean circulation and increased melting under Pine Island Glacier ice shelf. Nat. Geosci. 4, 519-523. doi: 10.1038/ngeo1188
Jickells, T. D., An, Z. S., Andersen, K. K., Baker, A. R., Bergametti, G., Brooks, N., et al. (2005). Global iron connections between desert dust, ocean biogeochemistry, and climate. Science 308, 67-71. doi: 10.1126/science.1105959

Johnson, K. S., Berelson, W. M., Boss, E. S., Chase, Z., Claustre, H., Emerson, S. R., et al. (2009). Observing biogeochemical cycles at global scales with profiling floats and gliders: prospects for a global array. Oceanography 22, 216-225. doi: 10.5670/oceanog.2009.81

Le Quere, C., Raupach, M. R., Canadell, J. G., Marland, G., Bopp, L., Ciais, P., et al. (2009). Trends in the sources and sinks of carbon dioxide. Nat. Geosci. 2, 831-836. doi: 10.1038/ngeo689

Levitus, S., Antonov, J., and Boyer, T. (2005). Warming of the world ocean, 1955-2003. Geophys. Res. Lett. 32, L02604. doi: 10.1029/2004GL021592

Lomas, M. W., Steinberg, D. K., Dickey, T., Carlson, C. A., Nelson, N. B., Condon, R. H., et al. (2010). Increased ocean carbon export in the Sargasso Sea linked to climate variability is countered by its enhanced mesopelagic attenuation. Biogeosciences 7, 57-70. doi: 10.5194/bg-7-57-2010

Manizza, M., Follows, M. J., Dutkiewicz, S., Menemenlis, D., Hill, C. N., and Key, R. M. (2013). Changes in the Arctic Ocean CO2 sink (1996-2007): a regional model analysis. Global Biogeochem. Cycles 27, 1108-1118. doi: 10.1002/2012GB004491

Marinov, I., Gnanadesikan, A., Toggweiler, J. R., and Sarmiento, J. L. (2006). The Southern Ocean biogeochemical divide. Nature 441, 964-967. doi: 10.1038/nature 04883

Marshall, G. J., Stott, P. A., Turner, J., Connolley, W. M., King, J. C., and Lachlan-Cope, T. A. (2004). Causes of exceptional atmospheric circulation changes in the Southern Hemisphere. Geophys. Res. Lett. 31, L14205. doi: 10.1029/2004 GL019952

Martz, T. R., Connery, J. G., and Johnson, K. S. (2010). Testing the Honeywell Durafet ${ }^{\circledR}$ for seawater $\mathrm{pH}$ applications. Limnol. Oceanogr. Methods 8, 172-184. doi: 10.4319/lom.2010.8.172

Miller, S. D., Marandino, C., and Saltzman, E. S. (2010). Ship-based measurement of air-sea CO2 exchange by eddy covariance. J. Geophys. Res. Atmos. 115, D02304. doi: 10.1029/2009JD012193

Muller-Karger, F. E., Varela, R., Thunell, R., Luerssen, R., Hu, C., and Walsh, J. J. (2005). The importance of continental margins in the global carbon cycle. Geophys. Res. Lett. 32, L01602. doi: 10.1029/2004GL021346

Myhre, G., Shindell, D., Bréon, F. M., Collins, W., Fuglestvedt, J., Huang, J., et al. (2013). "Anthropogenic and natural radioative forcing," in Climate Change 2013: The Physical Science Basis. Contribution of Working Group I to the Fifth Assessment Report of the Intergovernmental Panel on Climate Change, eds T. F. Stocker, D. Qin, G.K. Plattner, M. Tignor, S. K. Allen, J. Boschung, et al. (NewYork, NY: Cambridge University Press), 659-740.

Nevison, C., Butler, J. H., and Elkins, J. W. (2003). Global distribution of $\mathrm{N} 2 \mathrm{O}$ and the $\triangle \mathrm{N} 2 \mathrm{O}-\mathrm{AOU}$ yield in the subsurface ocean. Global Biogeochem. Cycles 17, 1119. doi: 10.1029/2003GB002068

Nevison, C. D., Weiss, R. F., and Erickson, D. J. (1995). Global oceanic emissions of nitrous oxide.
J. Geophys. Res. Oceans 100, 15809-15820. doi: 10.1029/95JC00684

Nielsdóttir, M. C., Moore, C. M., Sanders, R., Hinz, D. J., and Achterberg, E. P. (2009). Iron limitation of the postbloom phytoplankton communities in the Iceland Basin. Global Biogeochem. Cycles 23, GB3001. doi: 10.1029/2008GB003410

Nishioka, J., Obata, H., and Tsumune, D. (2013). Evidence of an extensive spread of hydrothermal dissolved iron in the Indian Ocean. Earth Planet. Sci. Lett. 361, 26-33. doi: 10.1016/j.epsl.2012.11.040

Planquette, H., Sherrell, R. M., Stammerjohn, S., and Field, M. P. (2013). Particulate iron delivery to the water column of the Amundsen Sea, Antarctica. Mar. Chem. 153, 15-30. doi: 10.1016/j.marchem.2013.04.006

Rabalais, N. N., Turner, R. E., Díaz, R. J., and Justic, D. (2009). Global change and eutrophication of coastal waters. ICES J. Mar. Sci. 66, 1528-1537. doi: 10.1093/icesims/fsp047

Regnier, P., Friedlingstein, P., Ciais, P., Mackenzie, F. T., Gruber, N., Janssens, I. A., et al. (2013). Anthropogenic perturbation of the carbon fluxes from land to ocean. Nat. Geosci. 6, 597-607. doi: 10.1038/ngeo1830

Rérolle, V. M. C., Floquet, C. F. A., Mowlem, M. C., Connelly, D. P., Achterberg, E. P., and Bellerby, R. R. G. J. (2012). Seawater-pH measurements for ocean-acidification observations. Trends Anal. Chem. 40, 146-157. doi: 10.1016/j.trac.2012.07.016

Saito, M. A., Chisholm, S. W., Moffett, J. W., and Waterbury, J. (2002). Cobalt limitation and uptake in the marine cyanobacterium Prochlorococcus. Limnol. Oceanogr. 47, 1629-1636. doi: 10.4319/lo.2002.47.6.1629

Schlosser, C., Klar, J. K., Wake, B. D., Snow, J. T., Honey, D. J., Woodward, E. M. S., et al. (2014). Seasonal ITCZ migration dynamically controls the location of the (sub)tropical Atlantic biogeochemical divide. Proc. Natl. Acad. Sci. U.S.A. 111, 1438-1442. doi: 10.1073/pnas.1318670111

Simpson, J. H., and Sharples, J. (2012). Introduction to the Physical and Biological Oceanography of Shelf Seas. Cambridge: Cambridge University Press. doi: 10.1017/CBO9781139034098

Steinacher, M., Joos, F., Frölicher, T. L., Bopp, L., Cadule, P., Cocco, V., et al. (2010). Projected 21st century decrease in marine productivity: a multimodel analysis. Biogeosciences 7, 979-1005. doi: 10.5194/bg-7-979-2010

Stroeve, J., Holland, M. M., Meier, W., Scambos, T., and Serreze, M. (2007). Arctic sea ice decline: faster than forecast. Geophys. Res. Lett. 34, L09501. doi: 10.1029/2007GL029703

Timmermans, K. R., Wagt, B., and De Baar, H. J. W. (2004). Growth rates, half saturation constants, and silicate, nitrate, and phosphate depletion in relation to iron availability of four large open-ocean diatoms from the Southern Ocean. Limnol. Oceanogr. 49, 2141-2151. doi: 10.4319/lo.2004.49.6.2141

Wyatt, N. J., Milne, A., Woodward, E. M. S., Rees, A. P., Browning, T. J., Bouman, H. A., et al. (2014). Biogeochemical cycling of dissolved zinc along the GEOTRACES South Atlantic transect GA10 at $40^{\circ} \mathrm{S}$. Global Biogeochem. Cycles 28, 2013GB004637. doi: 10.1002/2013GB004637 
Conflict of Interest Statement: The author declares that the research was conducted in the absence of any commercial or financial relationships that could be construed as a potential conflict of interest.

Received: 03 April 2014; accepted: 21 April 2014; published online: 07 May 2014.
Citation: Achterberg EP (2014) Grand challenges in marine biogeochemistry. Front. Mar. Sci. 1:7. doi: 10.3389/fmars.2014.00007

This article was submitted to Marine Biogeochemistry, a section of the journal Frontiers in Marine Science.

Copyright () 2014 Achterberg. This is an open-access article distributed under the terms of the Creative
Commons Attribution License (CC BY). The use, distribution or reproduction in other forums is permitted, provided the original author(s) or licensor are credited and that the original publication in this journal is cited, in accordance with accepted academic practice. No use, distribution or reproduction is permitted which does not comply with these terms. 